\begin{tabular}{lrllll}
\hline Consensus & RRRCW & WGYYY & (N) ${ }_{0-13}$ & RRRCW & WGYYY \\
Human FAC sequence & ${ }^{1848}$ AGACA & TGTTC & C & AGAC & AGTTC ${ }^{1828}$ \\
Mouse FAC sequence & ${ }^{2010}$ AGACA & TGTTC & C & AGAC $\underline{C}$ & AGTTC
\end{tabular}

$B$ Leucine zipper motifs

Consensus

Human FAC sequence

Mouse FAC sequence

LXXXXXXLXXXXXXLXXXXXXL--LXXXXXXLXXXXXXLXXXXXXI

${ }^{38}$ VAQFQEFLRKMYEALKEMDSNT ${ }^{59}-^{-234}$ LPMSAVVCLWLRHLPSLEKAMLHL ${ }^{25}$

${ }^{38}$ LSGFQEFLRQMYEILKEMDSDAIL ${ }^{61}$-- $^{235}$ VPTSSVVSLWFRHLPSLEKATLHL ${ }^{258}$

repeats. The second of the zipper motifs is preceded both by a helix-turn-helix region (with the crucial glycine at position 208) and a distinctly basic domain (position 160 to 176). The picture that emerges (figure) is that of a prototype nuclear protein designed to interact both with DNA and proteins. ${ }^{9}$ The strong conservation between the murine ${ }^{10}$ and human motifs (table) argues for their functional significance: the conservation amounts to $100 \%$ for the p53 binding site motif ( $v$ $78 \%$ in the remainder of the sequence), and to $90 \% v 79 \%$ for the amino acid residues within the leucine zipper domains.

The apparent contradiction between nuclear ${ }^{11}$ and cytoplasmic location ${ }^{1213}$ of the FAC protein can be reconciled if one assumes that the inactive bulk of the protein is located in the cytoplasm, and that transfer into the nucleus and subsequent activation occurs only in response to DNA damage.

WOLFGANG LIEBETRAU MANFRED BÜHNER HOLGER HOEHN Institut für Humangenetik, Biozentrum, University of Würzburg, Am Hubland, 97074 Würzburg, Germany.

1 Walsh CE, Grompe M, Vanin E, et al. A functionally active retrovirus vector for gene therapy in Fanconi anemia group C. Blood 1994, 84:453-9.

2 Strathdee CA, Gavish H, Shannon WR, Buchwald M. Cloning of CDNAs for Fanconi's anemia by functional complementation. $\mathrm{Na}$ ture 1992;356:763-7.

3 Whitney MA, Saito H, Jakobs PM, Gibson RA, Moses RE, Grompe MA. Common mutation in the FACC gene causes Fanconi anemia in Ashkenazi Jews. Nature Genet 1993;4:202-5.

4 Verlander PC, Lin JD, Udono MU, et al. Mutation analysis of the Fanconi anemia gene FACC. Am ₹ Hum Genet 1994;54:595-601.

5 El-Deiry WS, Scott EK, Pietenpol JA, Kinzle KW, Vogelstein W. Definition of a consensus binding site for p53. Nature Genet 1992;1: 45-9.

6 Schärer E, Iggo R. Mammalian p53 can function as a transcription factor in yeast. Nucleic Acids Res 1992;20:1539-45.

7 Juven T, Barak Y, Zauberman A, George DL Juven T, Barak Y, Zauberman A, George DL,
Oren $M$. Wild type p53 mediate sequenceOren $M$. Wild type p53 mediate sequence-
specific transactivation of an internal promoter specific transactivation of an internal promoter with.

8 Wang XW, Forrester K, Yeh H, Feitelson MA, $\mathrm{Gu} J$, Harris CC. Hepatitis B virus X protein inhibits p53 sequence-specific DNA binding transcriptional activity, and association with transcription factor ERCC3. Proc Natl Acad Sci USA 1994;91:2230-4.

9 Kouzarides T, Ziff E. The role of the leucine zipper in the fos-jun interaction. Nature 1988 336:646-51.

10 Wevrick R, Clark CA, Buchwald M. Cloning and analysis of the murine Fanconi anemia group C cDNA. Hum Mol Genet 1993;2:65562

11 Gavish H, Clarke CA, Shannon WR, Buchwald $M$. The Fanconi anemia (FACC) protein is primarily localized in the nucleus. Am $\mathcal{f}$ Hum Genet 1993;53:685.

12 Yamashita T, Barber DL, Zhu Y, Wu N, D'Andrea $\mathrm{AD}$. The Fanconi anemia polypeptide FACC is Acad Sci USA 1994;91:6712-16.

13 Youssoufian H. Localization of Fanconi anemia C protein to the cytoplasm of mammatia

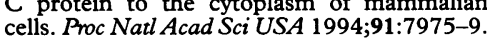

\section{The COX8 gene is not the disease gene of the CMH4 locus in familial \\ hypertrophic cardiomyopathy}

Familial hypertrophic cardiomyopathy (FHC) is an autosomal dominant disorder characterised by ventricular hypertrophy which mainly affects the interventricular septum and causes severe myocardial and myofibrillar disarray. ${ }^{12}$ FHC is genetically heterogeneous. Four loci have been identified: $\mathrm{CMH} 1$ on chromosome $14, \mathrm{CMH} 2$ on chromosome $1, \mathrm{CMH} 3$ on chromosome 15 , and $\mathrm{CMH} 4$ on chromosome 11 , and a fifth locus exists. ${ }^{3}$ On these loci, three genes have been identified, respectively encoding the cardiac sarcomeric proteins $\beta$ myosin heavy chain, troponin $T$, and $\alpha$ tropomyosin. ${ }^{45}$ For these three genes, there is also allelic heterogeneity. ${ }^{3}$ The gene implicated in the CMH4 locus ${ }^{6}$ is not yet known. We attempted to ascertain whether the gene COX8, which is localised at $11 \mathrm{q} 12-\mathrm{q} 13$ and encodes the subunit VIII of the cytochrome c oxidase complex (COX) ${ }^{7}$ is the CHM4 disease gene. COX is the terminal enzyme of the mitochondrial respiratory chain and participates in the production of ATP through oxidative phosphorylation. ${ }^{8}$ Therefore, an alteration of a gene encoding one of the COX subunits might modify ATP production in the cell, leading to a compensatory myocardia hypertrophy. Furthermore, several deficiencies in COX activity have been described in hypertrophic cardiomyopathies. ${ }^{910}$ All these characteristics made the COX8 gene good candidate for the $\mathrm{CMH} 4$ locus, and analyses were performed on family 714 in which this locus was described.
Since the genomic structure of the COX8 gene is not known, Southern blot analysis was carried out, as described in Schwartz et $a l,{ }^{11}$ in a search for deletions or insertions or both, using COX8 cDNA as specific probe. ${ }^{12}$ The DNA of 60 people, 11 of whom were affected, was analysed after digestion with 12 restriction enzymes (BamHI, $B c l \mathrm{II}, B g l \mathrm{II}$, EcoRI, EcoRV, HindIII, HinfI, MspI, PstI, PvuII, RsaI, and TaqI). The results showed no difference between the DNA of affected and healthy people as regards the length of the DNA fragments shown (data not shown), indicating that there were no major modifications in the genomic structure of the COX8 gene.

The next step was to look for alterations in the mRNA. Since the COX8 gene is ubiquitously transcribed, ${ }^{7}$ northern blot analyses were performed, using $10 \mu \mathrm{g}$ of total RNA purified from lymphoblastoid cell lines of four affected and four healthy people, and COX8 cDNA was used as specific probe. ${ }^{12}$ These analyses showed no differences between the length of COX8 mRNA in healthy and affected members of the family. Individual COX8 mRNAs were further quantified, using $18 \mathrm{~S}$ RNA as internal probe. The ratios of COX8 mRNA/18S RNA were as follows: for the affected subjects, $0.62,0.69,0.63$, and 0.54 respectively, and for the healthy subjects, $0.55,0.61,0.66$, and 0.70 . These results showed no significant differences in mRNA levels. Consequently, the absence of major alterations in COX8 transcripts enabled us to exclude the possible presence of mutations in intronic splicing sites, which would have led to transcript deletion or insertion or both.

Lastly, COX8 transcripts were sequenced. Reverse transcription and amplification of COX8 mRNA (RT-PCR) were carried out with $1 \mu \mathrm{g}$ of total RNA purified from lymphoblastoid cell lines of four affected and four healthy people. The strategies of am-

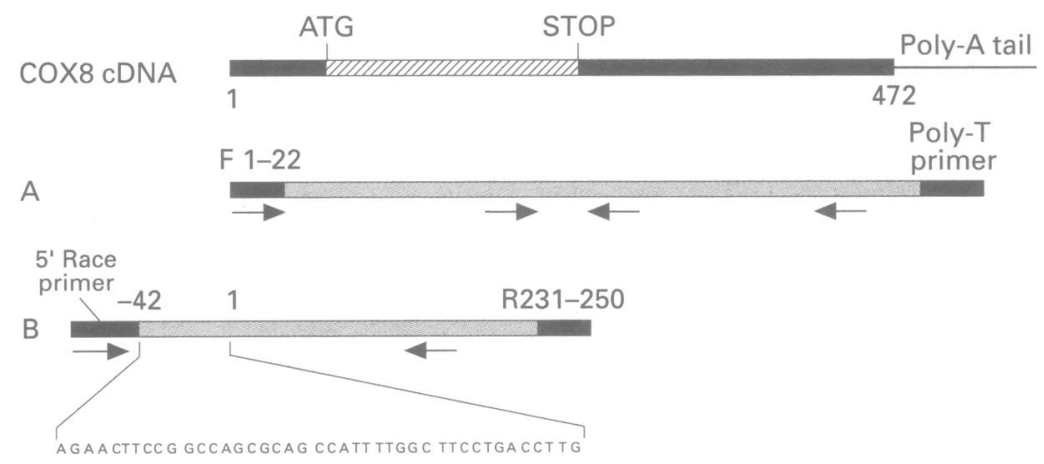

COX8 cDNA amplification and sequencing strategies. COX8 cDNA is depicted as described in Rizzuto et al. ${ }^{\top}(A)$ Reverse transcription and amplification using poly-T primer and F 1-22 specific primer. (B) Amplification of $c D N A 5^{\prime}$ end using the 5'-RACE method. reverse transcription of COX $\mathrm{cDNA}$ with $R$ 231-250 specific primer, followed by addition of a poly-C tail at the $5^{\prime}$ end of this $c D N A$, on which what is termed a $5^{\prime}-$ $R A C E$ primer is anchored, to amplify the DNA fragment with the R230-250 specific primer. Arrows indicate the different sequencing steps of DNA fragments $A$ and $B$. The hitherto unidentified sequence of 42 nucleotides at the $5^{\prime}$ end of the cDNA is also presented. 
plification and sequencing are shown in the figure. A first strand cDNA synthesis kit (Pharmacia) with poly-T primer and specific COX8 primer (F 1-22) was used for CDNA amplification between nucleotides 22 and 472 (figure A), according to the nucleotide numbers reported by Rizzuto et al. ${ }^{7}$ The $5^{\prime}$ end of COX8 cDNA, before nucleotide 22, was amplified with the 5'-RACE kit (Life Technology/Gibco-BRL) and specific COX8 primer (R 231-250, figure B). Overlapping PCR fragments were sequenced using the dideoxynucleotide chain termination method with fluorescent dideoxynucleotides on an Applied Biosystem 373A DNA sequencer (Perkin Elmer/ABI). We found a hitherto unidentified sequence of 42 nucleotides a the $5^{\prime}$ end of the CDNA, and the rest of the COX8 cDNA sequence was identical to that previously described by Rizzuto et $\mathrm{ll}^{7}$ (figure). From nucleotides -42 to +472 , there were no mutations in either the affected or healthy people in the COX8 cDNA.

The promoter region of the COX8 gene, the part of the gene that has not yet been identified, was not analysed. However, all the mutations so far identified in FHC have been described, either in the coding regions of the gene (mutations in MYH7 encoding the $\beta$ myosin heavy chain ${ }^{3}$ ), or in an intronic splicing site (mutation in the splice donor sequence of intron 15 of the cardiac troponin T gene $\left.{ }^{5}\right)$. By analogy with all the data available for FHC, we therefore conclude that the COX8 gene is very unlikely to be the disease gene of the $\mathrm{CMH} 4$ locus responsible for FHC.

We are indebted to the family members for their invaluable participation. We are also grateful to $J$ Weisle participation. We are also grateful to Weissenbach, and $C$ Caloustian for their help in sequencing at the Genethon (Evry, France) and to L Fetler, O Dubourg, A Hagege, J B Bouhour, and $\mathbf{R}$ Isnard for their contribution to clinical diagnoses. This work was supported by INSERM (Réseau de recherche clinique No 492010) and the Association Française contre les Myopathies. GB is recipient of a grant from the Foundation Bettencourt-Schuller.

\section{GISELE BONNE LUCIE CARRIER KETTY SCHWARTZ Unité de Recherche 153 de l'INSERM,
Pavillon Rambuteau, Group Hospitalier Pitié-Salpétrière 47 Boulevard de l'Hôpital 75651 Paris CEDEX 13, France. MICHEL KOMAJDA Service de Cardiologie, Groupe Hospitalier Pitié-Salpétrière, Paris, France.}

1 Maron BJ, Ferrans VJ. Ultrastructural features of hypertrophied human ventricular myocardium. In: Progress in cardiovascular diseases. 1978:207-38.

2 Maron BJ, Nichols PF, Pickle LW, et al. Patterns of inheritance in hypertrophic cardiomopathy. Assessment by $\mathrm{M}$-mode and two-dimensional echocardiography. Am $f$ Cardiol 1984;53: 1087-94.

3 Schwartz K, Carrier L, Guicheney P, Komajda $M$. The molecular basis of familial cardiomyopathy. Circulation 1995;91:1-9.

4 Geisterfer-Lowrance AAT, Kass S, Tanigawa G, et al. A molecular basis for familial hypertrophic cardiomyopathy: a $\beta$ cardiac myosin heavy chain gene missense-mutation. Cell 1990;62:999-1006.

5 Thierfelder L, Watkins $\mathrm{H}$, MacRae C, et al. $\alpha$ tropomyosin and cardiac troponin $T$ mutation cause familial hypertrophic cardiomyopathy: disease of the sarcomere. Cell 1994;77:701-12.

6 Carrier I Hengstenberg C, Beckmann JS, et al. Mapping of a novel gene for familial hy pertrophic cardiomel gene for familial hypertrophic cardiomyopathy to

7 Rizzuto R, Nakase H, Darras B, et al. A gene specifying subunit VIII of human cytochrome c oxidase is localized to chromosome 11 and is expressed in both muscle and non-muscle tissues. F Biol Chem 1989;264:10595-600.

8 Hatefi Y. The mitochondrial electron transport and oxidative phosphorylation system. Annu Rev Biochem 1985;54:1015-69.

9 Gournay-Toulemonde V, Munnich A, Bouhour $\mathrm{JB}$, et al. Hypertrophic cardiomyopathy caused by cytochrome c oxidase deficiency. Presse Med by cytochrome c oxic

10 Ozawa T. Mitochondrial cardiomyopathy. Herz 1994;19:105-18.

11 Schwartz K, Dufour C, Fougerousse F, et al. Exclusion of myosin heavy chain and cardiac actin gene involvement in hypertrophic cardiomyopathies of several French families. Circ Res 1992;71:3-8.

12 Bonne G, Seibel P, Possekel S, Marsac C, Kadenbach B. Expression of human cytochrome c oxidase subunits during fetal development. Eur f Biochem 1993;217:1099-107.

\section{BOOK REVIEWS}

If you wish to order or require further information regarding the titles reviewed here, please write to or telephone the BMJ Bookshop, PO Box 295, London WC1H 9JR. Tel 0171383 6244. Fax 0171383 6662. Books are supplied post free in the UK and for BFPO addresses. Overseas customers should add $15 \%$ for postage and packing. Payment can be made by cheque in sterling drawn on a UK bank or by credit card (Mastercard, Visa, or American Express) stating card number, expiry date, and full name. (The price and availability are occasionally subject to revision by the Publishers.)

Assessing Genetic Risks: Implications for Health and Social Policy. Editors L B Andrews, J E Fullarton, N A Holtzman, A G Motulsky. Committee on Assessing Genetic Risks, Division of Health Sciences Policy, Institute of Medicine. (Pp 338; £36.95) Washington, DC: National Academy Press. 1994. ISBN 0-309-04798-6.

This fascinating report provides a comprehensive account of the "promises and problems in genetic testing". The deliberations of the 20 committee members were informed by a series of papers and discussions at workshops, meetings, and a public forum.

The first 28 pages comprises the Executive Summary and provides the reader with a useful synopsis of the 70 plus recommendations. Many of their recommendations mirror those found in the Nuffield report on ethical issues in genetic screening (London: Nuffield Foundation, 1993). One example is the creation of a National Advisory Committee Working Group on Genetic testing to oversee professional practice and determine when new genetic tests are ready for wide scale use in medical practices. The Nuffield report proposes the setting up of a central coordinating body to review genetic screening programmes and monitor their implementation and outcome.

The report covers the following issues: Genetic testing and assessment; Laboratory issues in human genetics; Issues in genetic counselling; Public education in genetics; Personnel issues in human genetics; Financing of genetic testing and screening; Social, legal, and ethical implications of genetic testing; and Research and policy agenda.
The numerous references for each of these topics are situated at the end of each chapter. The report continuously emphasises the need to respect the autonomy of people in the way they use genetic information.

I was delighted to see two pages devoted to "Recognizing Social and Cultural Differences". The report identified the need for a variety of information and education on genetics, with balanced descriptions, in a culturally acceptable manner and at an appropriate time. I found the term "teachable moment" a very useful concept (that is, when the person is most able to comprehend the full significance of the information). $\mathrm{Re}$ commendations about developing innovative information materials such as interactive computer systems were noted on several occasions. As in the Nuffield report, reference is made to the training needs of primary care practitioners.

It is of interest that the Chairman of the Committee (A G Motulsky) felt the need to add a separate note to the Preface. In it he pointed out that while the majority of the committee favoured voluntary participation in neonatal screening, a minority felt that mandatory screening for phenylketonuria (PKU) and hypothyroidism would be a simpler solution.

On a more personal note, he stated that information about sickle cell trait that is incidentally detected in neonatal screening is difficult to withhold and should be given to the mother with appropriate genetic counselling. This seems to be in contrast to the more confusing recommendation of the report: "When carrier status may be incidentally determined in newborn screening (eg, in sickle cell screening), parents should be informed in advance about the benefits and limitations of genetic information, and that this information is not relevant to the health of their child. If they ask for the results of the incidentally determined carrier status for their own reproductive planning, it should be communicated to them in the context of genetic counselling, and they should be informed that misattributed paternity could be revealed."

This has been a most enjoyable book to read and I would strongly recommend it to anybody interested in the broader issues raised by genetic screening and testing.

ELIZABETH N ANIONWU

Genetics in Neurology. Bailliere's Clinical Neurology. Editor A E Harding. (Pp 452; £27.50) UK: Harcourt Brace. 1994.

How much of this rapidly expanding field can you cover in 452 pages (including references and index)? To their credit, the editor and authors of this text have included all the inherited neurological diseases which are likely to be of major interest to clinical neurologists and clinical geneticists. In addition, judging by the number of times this reviewer's copy was borrowed, molecular geneticists working with these diseases will also find the chapters enlightening.

The chapters are all well written, comprehensible, and, in addition to providing excellent reviews of their subjects, provide an insight into the issues of genetic and phenotypic heterogeneity as they relate to the specific disease groups. The chapters on hereditary ataxias (Banfi and Zoghbi) and 